\title{
EU AND NATO, NEED FOR A COHERENT PARTNERSHIP
}

\author{
Ferdinand Gjana, PhD \\ Department of Law, Hena e Plote Beder University
}

Tirana, Albania

Abstract

The United States and its European allies share a common commitment to global order, moderated by the quest of global justice. So long as the Soviet Union stationed its armies across central Europe, the overriding common interest of maintaining the security and freedom of Western Europe held the Atlantic Alliance together. Underneath this, however, interests (and perceptions of interests) had diverged from the 1960s onwards, as American security concerns focused more on Southeast Asia and the Persian Gulf, while European governments explored the possibilities of détente within their own region. Since 1990, different geopolitical positions have driven US and European interests apart. Different trends in energy dependence and different understandings of climate change - have also shaped distinctive interests. Different levels of military capability in the projection of force have interacted with divergent understandings of the process of political, social and economic development, of the roots of terrorist movements and the pathology of aggressive state regimes. Widespread resistance within the USA to accepting the legitimacy of international law and of global institutions, rooted in the belief in the exceptional character of the U.S. Constitution and the self-evident morality of American policy, as well as in the self-evident supremacy of U.S. military power, has also widened the gap in interests and understandings across the Atlantic. In recent years, the most fundamental challenge to management of the EU-NATO relationship has been the combination of a United States drifting toward unilateralism and European concentration on creating an "autonomous" defence policy. Such natural but ominous tendencies could feed on one another, creating circumstances that could lead the transatlantic bargain from one crisis to another. This article deals with the EU-NATO relations and their views regarding the security and the partnership in general.

Keywords: EU, NATO, France, Turkey, ESDP

\section{The Hegemony Challenge}

The United States did not by itself create the circumstances that have left it as the world's only surviving superpower. But it does face the challenge of dealing; with this new reality. In recent years, the debate over US foreign policy among experts and editorialists has included those who argue for a more restricted US world role, and those who call for the United States to take full advantage of its position as the sole surviving superpower. Public opinion polls suggest that the American people reject both options, and in fact favor an engaged US world role based on sharing international burdens and responsibilities with other nations. ${ }^{1}$

At the end of the Cold War, President George H. W Bush clearly believed that the United States was required to play a strong international leadership role. Some of his advisers apparently thought the United States should use its position as the sole superpower to discourage challenges to that position, even among current allies. President Bush senior nonetheless

\footnotetext{
${ }^{1}$ Chicago Council on Foreign Relations polls over the last decade, as well as those from other polling organizations, have consistently shown that the vast majority of those questioned support an active US role in the world, sharing burdens with other countries through multilateral organizations like the United Nations and NATO. For polling data see reports located at ww.ccfr.org/globalviews2004/sub/pdf/2002_US_ Report.pdf and www.transatlantictrends.org/ [accessed December 9, 2004].
} 
accepted the importance of building consensus in the United Nations and constructing coalitions to deal with international challenges (both illustrated by his orchestration of the response to Iraq's invasion of Kuwait).

In the first year of his presidency, Bill Clinton and his foreign policy advisers experimented with a number of different approaches to US foreign policy. President Clinton sought to convert his successful campaign slogan, "It's the economy, stupid," into a pillar of US foreign policy. Early on, many friends and allies of the United States worried that the United States was turning inward, or at least away from Europe. Those concerns were heightened by the Clinton administration's initial "tilt" toward Asia (1993), the US reaction to the peacekeeping disaster in Somalia (1993), US reluctance to become deeply involved in the conflict in the former Yugoslavia (1991-1994), and an emerging tendency toward "self-deterrence," in which the United States appeared to be less and less inclined to risk the use of military force on behalf of international stability.

As Clinton moved toward the end of his first term, however, he appeared to have decided that an assertive US international leadership role could be more of an advantage than a burden. In 1996, as he campaigned for a second term in office, President Clinton argued that the United States was the world's "indispensable power," suggesting the international system required the active involvement of the United States to function effectively. Clinton maintained that such activism was in the U.S. best interest.

The Clinton administration for the most part attempted to avoid policies that were, or could be, perceived as isolationist or unilateralist. But, on occasion, it misjudged or chose to ignore how its actions would be seen by its friends and allies. The administration was also pushed by Congress in some directions that apparently would not have been its first choice-for example, on the issues of extraterritorial sanctions and nonpayment of US arrears at the United Nations. Administration setbacks in Congress over payment of UN arrears and "fast track" authorization for international trade negotiations were perceived abroad as further evidence of unilateralist tendencies.

In addition, self-confident US behaviour on occasion rubbed many Europeans the wrong way. When the Clinton administration revealed its choice of three candidates, Poland, the Czech Republic, and Hungary to participate in the first wave of NATO enlargement, many allies privately applauded. But the fact that the United States appeared to have abandoned the process of NATO consultations to make its choice clear, and then said its decision was non-negotiable, troubled even America's closest allies. It strengthened the hand of those in Europe who claimed that the United States was acting like a "hegemonic" power, using its impressive position of strength to have its way with its weaker European allies.

Whatever the explanation, U.S.-European relations would have been better served by a US approach that allowed the outcome to emerge more naturally from the consultative, behind-the-scenes consensus-forming process. In NATO councils, votes are weighed, not counted, and the US vote carries more weight than any other. The final result would have been the same and the appearance of a US "diktat" to the allies would have been avoided.

The George W. Bush administration came to office in 2001 facing a mix of European fears and expectations. Candidate Bush had made some statements suggesting the United States should begin to pull back from some of its overseas commitments, but the overall thrust of administration policy was in unilateralist directions, at least as seen by most Europeans.

The first foreign policy actions of the Bush administration tended to raise warning flags for European governments. Unilateral U.S. decisions not to join in the International Criminal Court, to remain outside the Kyoto Protocol on greenhouse gas emissions, and to terminate the Anti-Ballistic Missile Treaty with Russia were all seen as signs that the United States was heading in new directions based almost exclusively on short-term U.S. policy choices and with no regard for their impact on the views or interests of its closest allies.

After $9 / 11$, the approach taken by the Bush administration during the early stages of the war against terrorism, beginning with the campaign in Afghanistan, produced mixed reactions. On the one hand, the administration's strategy was based on building a broad international coalition against terrorism. The rhetoric and formal approach of U.S. policy remained true to this 
goal. On the other hand, the United States conducted the campaign with little reference to offers from the allies to help out and without making much institutional use of the NATO framework.

U.S. management of alliance relations during George W. Bush's first term demonstrated that if the United States appears to be overbearing in its relations with other countries, it may find it difficult to build international consensus on behalf of its policies. There may be occasions when the United States should choose to pursue a dominating line, even at the expense of dissonance with its allies, when it feels that important interests are at stake. But there are costs associated with policies that build coalitions only by the use of overwhelming political force rather than by consultation, persuasion, and compromise. ${ }^{1}$

The underlying reality that the United States occupies a central and unmatched position in international politics will not change in the foreseeable future. This, German commentator Joe Joffe has argued, cannot be seen simply in classic balance of power terms. He argues that the United States is different from previous dominant powers: "It irks and domineers, but it does not conquer. It tries to call the shots and bend the rules, but it does not go to war for land and glory." Further, he argues, the dominating U.S. position is based on "soft" as well as "hard" power: "This type of power is a culture that radiates outward and a market that draws inward and rests on pull, not on push; on acceptance, not on conquest." ${ }^{2}$

Under these circumstances, the United States faces the challenge of using its power in ways that reflect U.S. values and draw on the American public's desire to cooperate with other countries while not inspiring opposition as a result of appearing too domineering. If U.S. allies still believe that U.S. leadership is essential on many international issues, as they apparently do, then their challenge is to express their criticism of U.S. leadership style in terms that are appropriate for frank and honest discussions among friends.

If the United States and its allies do not manage this issue effectively, it could intrude dramatically on a wide range of issues in which their common interests are likely served by pragmatic cooperation rather than conflict inspired by current international power realities. In particular, a healthy transatlantic relationship will require that the United States master the art of being a hegemon without acting like one.

\section{How to Pursue European Autonomy inside an Atlantic Community}

On the other side of this equation, there is the danger that the European Union's pursuit of ever-deeper integration and autonomy will divide the transatlantic partners. US interests would benefit from a European partner that could assume serious military burdens and play a more substantial role dealing with international security problems. However, the unintended consequences of international policies can be the most important, and threatening in the long run.

The United States has since the end of World War II actively supported the process of European integration and a stronger European role in defence. For most of the Cold War period, the United States, particularly the U.S. Congress, constantly berated the Europeans about their inadequate defence efforts. At the same time, however, the United States was growing accustomed to its role as the dominant alliance leader, and inadequate European defence efforts only enhanced U.S. predominance. Therefore, when the European allies pledged to include military aspects of security in the process of European integration, the United States had mixed emotions. On the one hand, a more substantial European defence effort would help relieve the United States of European and perhaps even some global defence burdens. On the other hand, serious European efforts promised to disturb what had become the normal balance of power and influence in the alliance.

1 For a more extended treatment of this issue see Stanley R. Sloan, Robert G. Sutter, and Casimir A. Yost, The Use of U.S. Power, Implications for U.S. Interests, Washington, D.C., Institute for the Study of Diplomacy, Georgetown University, 2004.

2 Josef Joffe, "How America Does It," Foreign Affairs, September/October 1997, 16. 
The United States made a serious effort in the mid-1990s to respond to the European desire to take on more responsibility for defence and to give the process of the European integration a meaningful security component by creating room within which a European Security and Defence Identity could grow within NATO. The following and alternate initiatives for a European Security and Defence Policy therefore created immediate US suspicions that the new approach would bypass the mechanisms and principles established between NATO and the Western European Union in the mid-1990s and replace them with arrangements that are more likely to create separate and even competing EU and NATO decision-making processes and commitments.

US concerns were perhaps exaggerated, but not entirely unwarranted. In spite of the EU's best intentions, there is the danger that ESDP could create artificial divisions and distinctions among NATO allies, undermining NATO's political cohesion. Perhaps even more important than duplicating U.S.INATO capabilities at a time when EU countries are not increasing spending on defence is the risk that ESDP and the demands of its institutional creations could encourage "we/they" distinctions between Europeans and the United States, and even among European members of NATO. In spite of all the declarations on behalf of transparency and cooperation, EU governments and officials may occasionally seek to promote the EU's or their own standing by distinguishing European from American or "NATO" positions. The United States and the European allies share a wide range of common interests and values, but they are not always identical and are not always pursued identically. NATO's "golden rule of consultation" does not eliminate such differences but provides a setting in which differing approaches can be compromised or at least accommodated. The dynamic of the new arrangements may impose subtle barriers to communication and compromise that did not exist before.

By way of example, U.S. suspicions of EU motivations were heightened in 2000 by reports that some EU officials and governments had pressured candidates for EU membership like the Czech Republic, Hungary, and Poland to support an EU "line" in the EU-NATO relationship. Apparently the tactic was suspended, but the incident illustrates the potential for the "autonomy" aspect of ESDP to divide the alliance into European and American components. ${ }^{1}$ Such US concerns were recalled to mind by the 2003 failed attempt of France, Germany, Belgium, and Luxembourg to make European Union defence cooperation even more separate from NATO.

There remains a potent residue of suspicion in Washington about France's intentions and likely behavior. Particularly with the United Kingdom as strongly committed to ESDP as it has become, there is a danger that it will become increasingly enmeshed in an anti-American device manipulated by French neo-Gaullists. In addition, successful French guidance of ESDP down an anti-American road could pull Germany in the same direction, undermining the close relationship that the United States and Germany developed during the Cold War and the post-Cold War transition period. The alignment of France and Germany against U.S. policy in Iraq demonstrated the potential for future deterioration in U.S.-German relations.

There is also the danger that ESDP could be used by some European countries to join forces with Russia and China in working against "US hegemony." Very little irritates US officials and experts more than European officials singing along with a chorus of Russian, Chinese, and Third World commentators against "US hegemony." Some past examples that raised hackles in Washington have included French President Chirac joining the Chinese, in a communique at the end of his state visit to Beijing in May 1997, in praising the virtues of a "multipolar world" - thin cover for criticism of US hegemony. In June 1997, on a state visit to Moscow, Chirac failed to dispute Russian President Yeltsin's view of a Europe organized between Russia, France, and other members of the European Union. This recalled all too clearly old Soviet proposals for a "European house" that excluded the United States. If ESDP were to become a European platform for criticism of the U.S. world role, it

1 When I met a senior French diplomatic official on this issue at a meeting in Paris, he denied that EU diplomats had taken any such approach. Several Central European officials participating in the meeting, however, subsequently told me that their governments had been lobbied to line up with the EU on certain issues regarding the EU-NATO relationship in support of their desire to become EU members. 
would probably spell the beginning of the end for the transatlantic alliance. In fact, transatlantic differences over Iraq have encouraged President Chirac to speak out even more strongly about the desirability of a "multipolar" world. ${ }^{1}$

An ESDP that focuses too strongly on "autonomy" could convince U.S. leaders and members of Congress that the United States is no longer needed or wanted as a security partner in Europe. During the Cold War, European allies occasionally expressed the concern that if they did too much for their own defence, the United States would decide it was no longer needed in Europe and pull out. For those who believe that the alliance is still vitally important for US interests, there is a concern that the appearance of greater European self-reliance (even before it becomes a fact) might lead U.S. political leaders and members of Congress to conclude that NATO and U.S. military involvement in Europe are no longer necessary. In 2000, Representative Douglas Bereuter, then a leading member of the NATO Parliamentary Assembly, warned, "It needs to be clear to our European Allies that the creation of competing institutions in Europe that detract from NATO's capabilities and solidarity would endanger public and congressional support for its commitment to the North Atlantic alliance."2

Another challenge will be in the area of defence industrial relations. There is a danger that U.S. unilateralism combined with the EU desire for "autonomy" will increase transatlantic trade and industrial tensions by supporting development of a "fortress Europe" mentality in defence procurement. This is an area where the United States can take much of the blame for the lack historically of a "two-way street" in transatlantic armaments trade and failure to devise ways of sharing new technologies with the European allies to help them participate in the "Revolution in Military Technology." ESDP does not necessarily require that Europe increase protectionism or favouritism for its own defence industries. Lagging far behind American defence firms in adjusting to post-Cold War market conditions, the necessary mergers and consolidations are finally beginning to rationalize the European defencee industrial base. The next logical step is for rationalization of the transatlantic industrial base through a variety of means. This next step would have to be facilitated by governments, and both the United States and the EU members would have to make alliance solidarity and cooperation a high priority to overcome existing barriers to transatlantic armaments cooperation. An EU that puts a higher priority on developing ESDP could easily put new obstacles in the way of alliance cooperation in armaments, and particularly in the way of purchasing U.S. systems. ${ }^{3}$

Future U.S. policy toward ESDP will in any circumstances remain conflicted. Bush administration and congressional concerns about negative consequences of ESDP are likely to increase in direct proportion to the emphasis EU governments put on "autonomy" when describing what they hope to accomplish in ESDP.

Even if the European constitution is ratified, a politically united Europe is not likely to emerge for many years perhaps not for many decades. It is difficult to imagine the EU nations making commitments in the defence area that are more farreaching than those they have made to political union at any given point in time. It seems very unlikely, in other words, that defence union can proceed ahead of political union; rather it must develop in parallel or lag somewhat behind the process of developing greater political cohesion among the member states. Unless and until the members of the European Union have achieved something approaching political union, the European Security and Defence Policy will remain an intergovernmental exercise, subject to variable perceptions of national interests among current and potential EU members.

Dealing with the process of transition from an alliance dominated by the United States to one that is somewhat more balanced between the United States and Europe will therefore be one of the major challenges for the transatlantic democracies in the years, probably decades, ahead. However, the degree to which the United States pursues unilateralist policies internationally is likely to intensify support in Europe for more cohesive European foreign policy and defence positions, even if on a purely intergovernmental level.

\footnotetext{
1 See, for example, the speech of Jacques Chirac, president of the French Republic, before the International Institute for Strategic Studies, London, November 18, 2004.

2 William Drozdiak, "US Seems Increasingly Uncomfortable with EU Defense Plan," International Herald Tribune, March 6, $2000,8$.

${ }^{3}$ For an excellent survey of transatlantic defense industrial issues see Burkard Schmitt, editor, with Gordon Adams, Christopher Cornu, and Andrew D. James, "Between Cooperation and Competition: The Transatlantic Defence Market," Chaillot Papers, Number 44, Western European Union Institute for Security Studies, January 2001.
} 
In these circumstances, one important factor in the U.S. attitude toward ESDP will be the persistent suspicion of French motivations. Many American officials and experts still see France as intent on pushing the United States out of Europe, in spite of the frequent and apparently sincere official French statements to the contrary. Many officials in the George W. Bush administration were very much involved in the dark days of U.S.-French relations on these issues toward the end of the first George H. W. Bush administration. Any sign that ESDP is developing anti-American roots would set off alarm bells all around Washington.

The fact that the British government has taken a clear lead on ESDP is both reassuring and distressing to Americans. ${ }^{1}$ It is reassuring because the United States knows and trusts its British friends, and believes that their instincts regarding transatlantic relations are almost always compatible with U.S. interests. Nevertheless, US officials may remain suspicious that the UK, having started the EU defence ball rolling, will not be able to exert sufficient influence on its future path.

Down the road, the tactics of European and US policymakers may occasionally lead to further bouts of EU-NATO competition, particularly as Central and Eastern European states try to adjust to the demands of membership in both organizations. The challenge will be to keep the competitive instincts of policymakers on both sides of the Atlantic under control in the interest of EU-NATO convergence.

A key question about ESDP and NATO remains that of what additional military responsibilities the European allies are capable of taking on in the near future. According to Michael Quinlan, one should be encouraged by the fact that "most European countries now accept that their forces should in the future be configured, equipped, trained, and available much more than before for expeditionary or similar use, in support of international order, rather than for direct homeland defence against massive aggression." 2

Governments of the European Union have attempted to address many U.S. concerns in the context of ESDP's development. Most of the U.S. concerns, however, could not be put to rest in the near term. The way in which ESDP evolves will determine its impact on EU-NATO relations. Management of the issue will therefore be a continuing challenge for U.S. and European officials for years to come.

\section{The Diplomatic Challenges: Turkey and France}

To overcome the obstacles on EU-NATO relations, a diplomatic campaign focused on the national capitals will be required. It must particularly engage those who are sceptical of EU-NATO cooperation.

\section{Turkey: "NATO" but not "EU"}

One of the first steps will be to overcome the obstacles Turkey has created to EU-NATO consultations and intelligence sharing. Periodic meetings between the NAC and PSC are the major channel of communication at the political level between the two institutions. In response to the EU decision to admit Cyprus as a member despite the continuing division of that island, Turkey has insisted that strategic dialogue in the NAC-PSC forum is restricted to those EU member states that also belong to NATO or the Partnership for Peace - criteria that exclude Cyprus and Malta. The EU insists that all 27 members must be allowed to participate in discussions that go beyond current Berlin Plus operations. As a result, for more than a year the NACPSC meetings discussed only the EU's mission to Bosnia. Attempts to discuss such issues as recent events in Ukraine or Darfur failed. Turkey has also limited the sharing of classified information between NATO and the EU by insisting that NATO classified information can only be shared with EU member states that have signed a security agreement with NATO. Again,

\footnotetext{
1 Stanley R. Sloan, NATO, THE European Union and the Atlantic Community: The Transatlantic Bargain 2005, p.212.

${ }^{2}$ Quinlan, European Defense Cooperation, 54.
} 
Cyprus and Malta are excluded. As a result, NATO classified information can only be given to the EUMS if the latter ensures that its Cypriot and Maltese officers will not have access to that material. ${ }^{1}$ In June 2005, Turkey agreed that Darfur and a few other topics could be discussed in an "informal forum" and also agreed to an informal meeting of all 32 NATO and EU foreign ministers. A few of these discussions have taken place, but it is not yet clear whether this represents a major breakthrough or a brief and temporary compromise.

Ideally, Turkey should be convinced that continuing its block of EU-NATO interaction is counter to its own interests. It does not contribute to Turkey's own ambitions for EU membership, nor has it moved the Cyprus conflict closer to resolution. Moreover, blocking EU-NATO interaction will only ensure that NATO members, including Turkey, have fewer opportunities to influence ESDP and will marginalize NATO from European discussions about a range of security issues. Despite the stakes, there has not been an energetic effort to overcome Turkish objections and few governments seem ready to make resolving this matter a priority. This should change. Given the crucial importance of EU-NATO cooperation in meeting the key security challenges facing the North Atlantic region, the current stalemate should not be allowed to persist.

Overcoming Turkey's objections is only a first step, not a final one, however. In the past, NAC-PSC meetings were usually rather stilted, with EU members sticking to a previously agreed position or refusing to discuss a topic because an EU position did not yet exist. Far more important will be creating a commitment to EU-NATO cooperation among those EU members who believe the Union is more likely to develop an independent military capability only if NATO is kept at arm's length.

\section{France: NATO for EU}

The greatest diplomatic challenge that remains is France. French policy toward the Alliance seems guided by the desire to prevent any opportunity for NATO or the United States to confine the EU, and this has led the French government to regard EU-NATO cooperation with suspicion. Convincing the French government to accept the necessity of a restructured transatlantic security relationship based on stronger EU-NATO ties will be crucial, but it will also be an enormous diplomatic undertaking. Although France left NATO's integrated military structure in 1966, it has continued to be active in NATO operations, making major contributions to NATO operations in Bosnia, Kosovo, and Afghanistan, as well as to the NRF. Its military-to-military relationships within the Alliance are considered excellent, and French officers are present at SHAPE. France clearly recognizes the importance of NATO as a provider of military experience and training, and seems determined to ensure that French troops remain able to operate in an Alliance context. Closer French attachment to NATO's military structure should be encouraged. The exclusion of the French military from U.S. run military exercises (in which the French had previously participated) in the wake of the Iraq disagreement was a step in the wrong direction.

Given that a French general served as the ISAF commander when the Eurocorps was the lead contributor, the question of France holding a NATO command, or even rejoining the integrated military structure, may be ripe for discussion.

France re-engaging with NATO is not just a military question, however. The success of this diplomatic effort will rest on convincing French policymakers that the United States genuinely supports the development of a strong ESDP. Deepening the U.S.-EU relationship on security issues will be an essential part of this strategy. U.S. officials will also have to overcome their skepticism about the legitimacy of autonomous EU operations. This re-engagement will not happen overnight. In the meantime, it should be recognized that French actions regarding NATO are sometimes more constructive than the rhetoric

\footnotetext{
${ }^{1}$ Turkey is not the only NATO or EU member to use Berlin Plus in this way. Shortly after the Turks lifted an earlier hold on the Berlin Plus arrangements at the end of 2001, Greece acted through the EU to put another block on the negotiations. Berlin Plus was only concluded after Greece lifted that hold in late 2002.
} 
would imply. Despite the assertion of some French officials that NATO does not belong in Africa, the NAC did agree to the Darfur mission, an agreement that could not have been achieved in the face of French objections. Focusing on French actions rather than statements may help provide the climate diplomacy needs to be successful.

The United States, should it undertake the recommended diplomatic initiative, will find strong support in many quarters. Poland, Britain, Denmark, and many of the new members would be enthusiastic. The new German government has a strong interest in revitalizing the Alliance. Thus, notwithstanding the challenges of achieving agreement with France and Turkey, the greatest challenge remains convincing the U.S. government to undertake the effort. Should it do so with enthusiasm and determination, there is no reason to rule out success?

\section{Common Interests in Different Continents}

Geographical position, again, makes for unavoidably different perceptions and priorities. China is a distant state, an economic competitor and a promising market to European states, but not in any sense a security threat; but to the United States, with its historical commitment to Taiwan and to Japan, China looms as a major security risk and political challenger. Russia is a strategic partner for the USA - but a direct neighbour of the EU, the dominant supplier for European gas, and a major concern to European states in terms of cross-border crime, drug trafficking, and illegal migration. Venezuela, Colombia, the small states of the Caribbean and Central America, of little interest to European foreign and defence ministries, preoccupy Washington for similar reasons.

The Muslim states around the southern and eastern Mediterranean relate to Western Europe almost as closely as Mexico does to the USA; more than 12 million first- and second-generation people of Turkish, Moroccan, Algerian, Tunisian, Kurdish, and even Palestinian origin live and work within the EU's borders. More will arrive, illegally as well as legally, within the next 10-20 years, however hard European governments attempt to keep them out; population pressures are powerful, economic opportunities enticing, and sea crossings easy to make.

Africa south of the Sahara is of much more direct concern to European states than to the USA, for which only energyproducing African states carry significant interest. Ex-colonial links and obligations, established patterns of migration, higher levels of trade and investment, spill overs of disorder and disease, force Britain, France, Portugal and Spain, to pay close attention to political and economic developments, and to intervene in the last resort to forestall state collapse, or contain cross-border conflicts.

It is the Middle East, however, where American and European perceptions of interests diverge most sharply. The continuing rise in US oil consumption and imports, unchecked by active conservation or tax policies, has increased American dependence on access to global oil markets over the past 15 years. The USA has held a dominant position as external hegemon across the Middle East throughout that period, balancing precariously between close alliance with Israel and partnership with the puritanical Islamic state of Saudi Arabia, strategically opposed to Shi'ite Iran. European governments have argued for a different approach to relations between Israel and the Palestinians, arguing that only a two-state solution, with a territorially-viable Palestinian state, can provide the long-term security that Israel needs. European policy makers have been more open to dialogue with Iran, and less complacent about Saudi support for Wahhabi Sunnism, including within Western Europe. The transatlantic divide over military intervention in Iraq did not open up in previously clear ground: it widened existing gaps in understanding and in domestic and international interests.

It therefore seems unwise to attempt to reorient NATO to become the vehicle for projecting Western forces across the Greater Middle East and Eurasia. There is insufficient basis for shared interpretation and interests to support joint action. NATO risks becoming Washington's preferred vehicle for multilateral action, at the expense of other multilateral institutions, because it operates under clear US leadership and direction. European allies have provided some support for post-conflict operations in Afghanistan, and several have provided post-conflict military forces in Iraq; but these have been reluctant 
contributions, for the most part, to operations over which non-Americans had little or no influence. Joint operations can only be maintained on the basis of shared objectives. It is no longer clear that European and American elites share common objectives, or assessments of the issues at stake, across the broad sweep of unstable states and societies between Europe and south and East Asia.

\section{Conclusions}

American rhetoric on Atlantic cooperation and consequently on EU-NATO relationships is often still inclined in terms of common visions and interests, contrasted with the irrational anti-Americanism of those who oppose American policies. On the European continent there is, against this, a temptation to define independence and social values against America, condemning the USA for pursuing political and economic hegemony through an explicit strategy of globalization. Each side in this ideological battle demands that the other should yield to their superior morality. It would be much more constructive to recognize our differences of values, and of interests, and to set out to manage those differences within the very broad framework of interests we share in maintaining global order and prosperity.

The intensity of disagreements, in recent years, has reflected into EU-NATO relations not to reach the optimal cooperation.

I have argued here for an acceptance of a greater degree of reasoned disagreement between American and European policy-makers and publics, reflecting their different geographical positions, visions, domestic pressures, and interests. That should, in turn, allow for a less emotional transatlantic dialogue: a partnership between North America and Europe, which means a partnership between EU and NATO, built not on a demand for others to accept contested 'shared values' but on the solid foundations of intensive economic interdependence, social interaction, and a dispassionate debate on the best means available to promote a sustainable and secure global order.

\section{References}

[1] Chicago Council on Foreign Relations polls over the last decade, as well as those from other polling organizations, have consistently shown that the vast majority of those questioned support an active US role in the world, sharing burdens with other countries through multilateral organizations like the United Nations and NATO. For polling data see reports located at ww.ccfr.org/globalviews2004/sub/pdf/2002_US_Report.pdf and www.transatlantictrends.org/ [accessed December 9, 2004].

[2] For a more extended treatment of this issue see Stanley R. Sloan, Robert G. Sutter, and Casimir A. Yost, The Use of U.S. Power, Implications for U.S. Interests, Washington, D.C., Institute for the Study of Diplomacy, Georgetown University, 2004.

[3] For an excellent survey of transatlantic defense industrial issues see Burkard Schmitt, editor, with Gordon Adams, Christopher Cornu, and Andrew D. James, "Between Cooperation and Competition: The Transatlantic Defence Market," Chaillot Papers, Number 44, Western European Union Institute for Security Studies, January 2001.

[4] Josef Joffe, "How America Does It," Foreign Affairs, September/October 1997, 16.

[5] Quinlan, European Defense Cooperation, 54.

[6] See, for example, the speech of Jacques Chirac, president of the French Republic, before the International Institute for Strategic Studies, London, November 18, 2004.

[7] Stanley R. Sloan, NATO, THE European Union and the Atlantic Community: The Transatlantic Bargain Challenged, Rowman \&Littlefield, 2005, p.212. 
[8] Turkey is not the only NATO or EU member to use Berlin Plus in this way. Shortly after the Turks lifted an earlier hold on the Berlin Plus arrangements at the end of 2001, Greece acted through the EU to put another block on the negotiations. Berlin Plus was only concluded after Greece lifted that hold in late 2002.

[9] When I met a senior French diplomatic official on this issue at a meeting in Paris, he denied that EU diplomats had taken any such approach. Several Central European officials participating in the meeting, however, subsequently told me that their governments had been lobbied to line up with the EU on certain issues regarding the EU-NATO relationship in support of their desire to become EU members.

[10] William Drozdiak, "US Seems Increasingly Uncomfortable with EU Defense Plan," International Herald Tribune, March 6, 2000, 8. 
